\title{
CHILD-CENTRISM IN THE CONTEXT OF MODERN PEDAGOGICAL THEORY AND PRACTICE
}

\section{Kvas O. V.}

\section{INTRODUCTION}

The relevance of child-centered ideas in the modern pedagogical theory and practice is difficult to dispute. It lies in the pedagogical heritage, both in the theoretical and practical. These ideas left behind the creators and continuers of child development in its daily world over the centuries: teachers, scientists, public and and educational figures, doctors, politicians, religious figures, lawyers, representatives of various power structures.Because of their activity, such sciences as pedology, pediatrics, child sociology, child psychiatry, age psychology, childhood history, pedagogical psychology, sociology of education, pedagogy of individualism, personal pedagogy, pedagogy of culture, national pedagogy were emerged.

Due to the activity of the representatives of the pedocentric direction in pedagogy, world scientific congresses and conferences strongly spoke in defense of the child: International Congress of Pedology (Brussels, 1911), International League of New Education (Calais, 1921), International Congress of Child Psychiatry (1955), Conference on Experimental Pedagogy (Geneva, 1959), International Conference on Alternative Education (Lodz, 1992).

Concern for the future of children brought together indifferent people in a number of public organizations and societies: the International Society for the Care of Children (1892), the International Pedological Society (1910), the International Organization for the Assistance to Children (1920), the Society of Children's Friends (1949), the United Nations Children's Fund - UNICEF (1953), World Foundation for Childhood 
(2000). The movement for the protection of the rights of children has also intensified. It was based on the recognition of the child's right to be interpreted by his human personality with his specific social, existential and individual problems. A number of international legislative acts have been adopted to regulate these issues: the Geneva Declaration of the Rights of the Child (1923), the First Protocol to the Convention on Human Rights and Fundamental Freedoms (1952), the Declaration on the Rights of the Child, approved by the United Nations General Assembly (1959), The International Convention on the Rights of the Child (1989), the introduction of the post of Commissioner for the Rights of the Child in Ukraine (2011) ${ }^{1}$.

The evolution of industrial societies and the intensification of individualization processes in modern education are causing increasingly qualitative changes in the learning culture. There is a decentralization of initiatives, responsibilities of competencies with the spread of the ideas of globalization.

In these circumstances, the school should become an environment where the pupils are important to society. Such a society needs educational institutions, where a new culture of learning exists, and its features have underpinned the pedagogy of child-centrism for many decades: recognizing the child as the central figure of the educational process, comparing of the pupil's to their own social experience with scientific knowledge, joint reflection on one's own actions in order to better absorb knowledge and continue initiated initiatives.

Based on above, the educational process is considered not only as a transfer of knowledge and development of skills, but also as a process of expanding, improving and updating existing cognitive schemes. What a child learns in school largely depends on what she already knows herself ${ }^{2}$.

\footnotetext{
${ }^{1}$ Illich I. Społeczeństwo bez szkoły. Warszawa : PIN, 1976. S. 219.

${ }^{2}$ Schoenebeck H. Thema Schule. Was Eltern und Lehrer schon tun kőnnen-20 Vorschlage, Freudschaft mit Kindern. Münster, 1981. P. 8-11.
} 
Creating an enabling environment for effective schooling, according to child-centered ideas, results in:

- the main emphasis in learning is placed on the research process of finding the truth, the nature of phenomena, connections in this process the key interest is the interest of pupil's;

- the primary competences of pupil are enriched, expanded and supplemented;

- pupil strive to achieve results that could increase educational potential;

- the teacher creates the conditions for creative activity of pupils in the lesson.

Thus, the purpose of learning is not to assimilate and reproduce teacher's transmitted knowledge and algorithmic skills, but to create knowledge by pupils. Learned in this way in the pupil's mind the knowledge have a dynamic, dialogical, emancipatory character. It becomes a part of the life experience and give the right to his own understanding of the world at the same time as being personally responsible for that understanding.

The creative model of teaching, sometimes referred to as constructive, is a modern carrier of ideas o child-centricity, enhanced by pedagogical cooperation. This model is built on a natural basis. The following requirements should be considered while using it at school:

- only through the social activities a child can be given the space to interpret his own experience, he learn to use the essence of cognitive phenomena in such a way that would meet the requirements of the cultural environment in which the child is (class, school, etc.); its activity is always perceived in a cultural and historical context.

- the pupil's must believe in himself as a learning person and also have the right to decide how to study;

- the teacher at school ceases to be the sole guarantor of the truth, but he is responsible for the methods, technologies and forms of organization 
of the educational process; such an approach is based on learning in a group (class) whose members, in the broadest sense of the word, collaborate in the process of learning, all pupil's are involved;

- the role of the teacher in the educational process changes from mentoring to mentoring (advisory, counseling), he becomes a person who defines the goal, proposes tasks, monitors the development of students, supports their activity, encourages cooperation ${ }^{3}$.

One of the major achievements of the creative school model, where the child builds his own knowledge, is the reliance on interpersonal relationships. The traditional model of teaching and learning overestimates the interaction «adult - child», «teacher - pupil».

This model is based on an anthropocentric approach to learning. Child-child interaction is displaced into the extracurricular environment. These relationships are an important component of the socialization of children, their cognitive, social and moral activities. It is obvious that the school will become more child-centered, more natural and organized so that learning, life and emotions will not be detached from it.

The ideas of child-centrism concerning the upbringing of a child remain extremely relevant for today.This is especially the case for marginalized children living in poverty and demoralization. These are children who don't find support in the family, at school, in educational and care institutions and are forced to seek friendly, safe feelings and, in fact, shelter on the street. Child-centrism in postmodern society must be deeply rooted in philosophy and social pedagogy.

Nowadays child-centrism explores not only the child, but also the world in which he lives. The study of the child's living space involves the study of the nature, patterns and actions of people who focus life activity on a small spatial segment. We can talk about the "geographical aspect" of specific realities that take place in the child's living space (city, district, street). It is important for the educator always keep in mind that social and

\footnotetext{
${ }^{3}$ Права дитини: від витоків до сьогодення: зб. текстів, метод. та інформ. матеріалів. Авт.-упоряд. Г. М. Лактіонова. К. : Либідь. 2002. 277 с.
} 
pedagogical and natural development are closely intertwined in the study of the child's living space. Social facts, including pedagogical ones, have a different origin than natural laws, their predictability is different. They can be understood only when they have come together, hence the need for their description, analysis and attempt to understand them ex post. It can be done by reconstructing historical and pedagogical researches and extrapolating them to modern pedagogical science and practice ${ }^{4}$.

Human rights begin with the rights of the child. If the rights of the child are part of the educational process and the education system, they increase greatly the value of both human and child rights and the education system itself.

The reorientation of modern social culture towards the mutual respect of rights adults and children reaffirms the view that adults should not be constantly overburdened with their obligations to children, otherwise it threatens to become their slaves; children also can't be granted by exclusive rights. It could lead to anarchy. There is no doubt that society must recognize the rights of the younger generation to freedom, dignity, lives, which would guarantee individual and public development. Responsibility for addressing this issue should be manifested through the combination of children's rights with their responsibilities.

In implementing a child-centered approach to the protection of the rights of the child by society, the last one should be aware that these are not rights that children should have or rights over which children would give themselves advice. Most likely, these one should be rights that serve children who should be respected, protected from being violated by other people, as well as created by a person, institutions (state, school, government) against disenfranchisement ${ }^{5}$.

If we say that human rights, as well as the rights of the child, derive from its nature, it means natural law, unwritten law, a right that is higher

\footnotetext{
${ }^{4}$ Права дитини: європейський досвід. упоряд. Н. М. Костяк. Львів: ПАІС. 2007. 113 с.

5 Лутай В. Філософія сучасної освіти. К. : Центр - Магістр - S - Творчої спілки вчителів України, 1996. $360 \mathrm{c}$.
} 
than the right established by man. Therefore, it is indestructible and cannot be disposed of. If adult society seriously violates this right by limiting or neglecting, it maintains the inevitable conflict between children and adults.

As modern law began to penetrate the relationship between children and adults, it changed and shifted from despotic-national to partnerbusiness, reinforcing on both sides the need for respect, love,trust, and an adjustment to ethical values and ideals.

The process of making children aware of their rights has an important educational dimension. It touches on the conscience of teachers, awakens the vulnerability of teachers and guardians to existing evil or pathology. Particular responsibility rests with those who have to stand up for the rights of the child in the state, namely, the child rights commissioner.

A difficult barrier to changing the legal status of a child is a family that adheres to the traditional approach to family education, which is the right of the family to raise the child as she sees fit. Sometimes it is even "breaking" personality. Each family establishes itself the right of public relations with the children to whom they should obey.

Increasingly, educators are pointing out $t$ the widespread myth of moral self-improvement for adults by respecting their children's rights is nothing more than a myth. This is evidenced by the fact that most European countries consider a child to be a child from birth to 18 years. Many of them don't have legislative acts or decrees governing the state's child protection policy. In fact, a child can't exercise any of its rights independently, but only through adults ${ }^{6}$.

According to R. Farson, “the emancipation of children doesn't mean the disappearance of any morality, but rather the rejection of its duality. Our relationships must be based on the same principles, moral beliefs and rights. How the actions of adults are subject to certain rules, systems of value and prescriptions, so children should. Because of the purpose of

\footnotetext{
6 Дитинство в Україні: права, гарантії, захист. голов. ред. В. І. Довженко. К.: АТ - Вид-во Столиця, 1998. 290 с.
} 
emancipatory aspirations is ultimately to reduce the possibility of mutual enslavement".

One of the important for the child is the right to self-development, because of this that he can free herself from violence and self-determination.

The child's right to life without physical punishment is also obvious. It applies to almost all situations of communication between children and adults, including school and out-of-school facilities. Removal from the educational practice of physical punishment, would encourage pedagogical workers to look for other ways and methods of working with children without causing offense to them.

Representatives of the modern antipedagogical direction believe that the school belongs to those institutions that destroy the human rights to freedom of education and thought. To their view, the school is not only an instrument of exercise of power through repressive-selection functions, but also a place of change of human nature in accordance with the Puritan outlook. After all, children in this case are considered "savages", who need to be constantly persuaded, directed and subjugated.

Antipedagogues claim that the learning process begins for everyone in a natural way from birth and can't be avoided or exempted. The only problem is whether or not the children want to learn under duress. Instead of maintaining good order in schools, parents should be more supportive of their own children and of their friendly teachers, for the sake of better and free upbringing.

Taking into account the axiological dimension of antipedagogy, it tends to gravitate towards a more personalistic direction in pedagogy, which in turn opens more opportunities for dialogue between personalism and antipedagogy, and also delineates the field of joint activity to create new relationships necessary for the pupil's personality between the child and a teacher. 
Among the most common pedagogical trends of the second half of the XX-th century, that actively implemented the idea of child-centrism was the critical-emancipation pedagogy that emerged on the basis of the critical theory of the Frankfurt School and the protest students' and students' movements in the late 1960-th. It was characterised by worldview ideas from liberal, critical-rationalist to orthodox-marxist ${ }^{7}$.

Essential for the critical direction in pedagogy was the change in the system of values and mentalities. It can be characterized as a transition from the nomocentric to the autocentric perception of the world. The "Nomocentric" considers itself an imperfect creature dependent on the social environment. This creature concentrates mainly on what was previously installed (nomos is the rule). "Autotsentryk" believe in their own strength and capabilities. A t the heart of this system is its values of rationality and ability to evaluate. The process of change of values can be characterized as the transition from values of the type "KON" (conservatism, conformism, conventionalism, controllability).

The school was criticized for such shortcomings as:

- school stresses due to student overload;

- low level of employment (old training programs, outdated teaching methods);

- dominance of object-subject approaches in training.

In contrast to such a school, representatives of this area sought a school that would:

- trusted in children, respected them as individuals;

- paid attention to all children without exception;

- created an atmosphere of goodwill at school.

The goals of critical emancipation education were as follows:

- resistance and resistance to conformism;

- critical rationality instead of irrationality serving the public interest;

- social change instead of reproducing what already exists;

\footnotetext{
$622 \mathrm{c}$.

${ }^{7}$ Гонтаровська Н. Б. Освітнє середовище як фактор розвитку особистості дитини. Д. : Дніпро. 2010.
} 
- cooperation and solidarity instead of struggle.

Critical emancipation pedagogy taught to resist to human abuse. First of all, it is about the grievances that a person experiences from society. According to the representatives of this field of pedagogy, children should not immediately receive ready knowledge and models of behavior. A key issue should be the development of an emerging generation of independence, critical thinking, creativity, and encouraging it to fight for social change ${ }^{8}$.

Much attention has been paid to child-centered ideas and the widespread humanistic psychology and pedagogy in the West. Particular merit in establishing this direction goes to the eminent scientists C. Rogers, A. Maslow and Ch. Buhler. Humanism and existentialism became the two most important sources of humanistic psychology and pedagogy. The motto of this direction should be considered the words of Ch. Buhler: "The idea of man as an active creator of his own being".

The main theses of humanistic psychology and pedagogy:

- the person is in the spotlight. Thus, the argument as the most important phenomenon in human cognition moves to the center;

- emphasis is placed on specific traits of human nature (ability to choose, creativity, self-affirmation, ability to evaluate);

- the choice of formulated questions and research methods in the knowledge of the child should be adequate to their significance;

- the main tenet of humanistic psychology and pedagogy is the respect for human values and dignity.

Teacher's and personality oriented learning processes are significantly different. In the first case, the teacher has the knowledge he has to impart, in the second - it is generally accepted that pupils can think and learn on their own. In the first case, the teacher has authority, the pupils are obedient, in the second - the responsibility for the learning process rests with everyone: the teacher, pupils, parents, society.

\footnotetext{
${ }^{8}$ Кремень В.Г. Філософія освіти ХХІ століття. Педагогіка і психологія: Вісник АПН Украӥни. 2003. № 1. C. 6-16.
} 
According to C. Rogers, "Young people are really very motivated to learn, open, overcome problems. Unfortunately, these traits after a few years spent at school in most cases disappear somewhere. But the motivation remains, and the task is to release again".

Constructivist pedagogy became very popular in German-speaking countries in the late XX-th century. The ideas of constructivism were first introduced by Austrian scientist P.Vatslavik in 1981. He published "Invented Reality". Constructivists consider any reality a design created by people who believe that they are discovering and exploring reality.

Constructivism is understood as the transition from the old to the new image of the world in simplistic terms: from a deterministic or mechanical image of the world, with a hierarchical division based on centralized management, on rationality and control to an undetermined, probable, decentralized image of the world consisting of numerous small, simple particles that create a network of partially stable, partially variable moves that can be always predicted ${ }^{9}$.

The success of modern constructivism, on the one hand, lies in its resemblance to cognitive psychology and system theory, as well as to phenomena such as individualization, postmodernism, and the crisis of normative disciplines (subjects) that are widespread in the modern world. The key competences of constructivist pedagogy are:

- openness to difference, pluralism, suspense;

- tolerance of differences, paradoxes and uncertainty;

- the ability and willingness to observe;

- responsibility for one's own and others' emotionality;

- the ability and willingness to make decisions and suggestions from others;

- openness to public issues and key issues.

All of the above gives reason to argue that child-centric ideas, like a hundred years ago, find their place in different fields of modern social science

\footnotetext{
${ }^{9}$ Щеглова С. Н. Как изучать детство? Социологические методы исследования современных детей и современного детства. М.: ТО ЮНПРЕСС, 2000. 72 с.
} 
maps, regardless of what system of ideological or political coordinates they are contained in. It can be stated that the problems of childhood was tried to solve by the society in the last centuries. It didn't become smaller but increased and became more difficult to solve than before.

If at the beginning of the last century, E. Kay called it the "Child's Age", in the end it turned out to be the century that saw two world wars, hundreds of wars between countries, thousands of religious armed conflicts, the same number of ethnic conflicts in which many died children, it is better XXI century not to call by high-pitched words, but to make sure that every adult remembers that the fate of future humanity depends on it, because it is in the hands of children. How we educate them, what we teach, and how we teach them will be the future.

XX-th century was characterized not only by the "educational outbursts" that led to a qualitatively higher level of educational development, but also by the "educational crises" that hindered this development. In particular, the first was the real dynamic development of education at every stage of schooling - from elementary, through secondary to higher and extra-curricular; the second is in many countries of the world. There is a continuing economic and political crisis that prevents education systems from development.

In nowadays world, education is increasingly democratized. Each civilized country develops its own education and training system, creating a national system. In each country, the existing education system has gone a long way of becoming and developing, under the influence of its own economic, political, social and cultural-educational conditions. Therefore, both developed and developing countries don't have quite similar education systems. However, there is much in common between these systems. In particular, it is a common cultural heritage that has 
significantly influenced and now influences the educational tradition of a particular people ${ }^{10}$.

Ukraine has been at the heart of civilizational challenges between East and West and, obviously, its cultural heritage has been significantly influenced by different peoples and civilizations not only geographically, economically, politically, but spiritually. At the same time, it was able to form and preserve her own authentic cultural tradition, including the educational one, that occupied a worthy place among the diversity of world pedagogical ideas, concepts, directions, movements.

It includes the development of child-centere ideas in domestic pedagogy. Ukraine may be proud of the fact that among the ideologists and theorists of the world at the very beginning of its pedagogical movement formation were domestic scientists S. Baley and I. Sikorsky. The first represented the Lviv School of Experimental Psychology, and the second the Kiev School of Experimental Psychology.

Ukraine went hand in hand with those available reform movements in Europe and the USA in the early XX-th century that set out to change the world of the child for the better. Important changes were made both in the system of education and in the system of upbringing, the purpose was to care for all categories of children and young people, care for them: orphans, homeless people, morally neglected, juvenile offenders, disabled children.

In Ukraine those areas of pedagogical activity have been developed, that is is called the theory of education, social pedagogy, and resocialization pedagogy. Here are some facts that illustrate the place of domestic educators in the world of pedagogical science: self-governmental children's republics of H. Lane and W. George (USA), institutions of absolute freedom for the troubled children of A. Neil (England); the colony and children's clubs of S. Shatsky (Russia), the work communes for homeless children A. Makarenko (Ukraine), the orphanage and the

\footnotetext{
10 Эриксон Э. Г. Детство и общество. 2-е изд., перераб. и доп. СПб. : Ленато : Фонд Университет. кн., 1996. 592 с.
} 
pedagogy "How to love a child" by J. Korczak (Poland), the "pedagogy of the heart" by V. Sukhomlinsky (Ukraine). It is in such a sequence that they are mentioned in modern classical foreign textbooks on pedagogy ${ }^{11}$.

"Pedagogy of the Heart" by a prominent Ukrainian teacher of the XX-th century V. Sukhomlinsky became a component of humanistic pedagogy. It advocated the protection of the rights and freedoms of the child, calls on each child to see a personality.

Modern ideas of child-centered pedagogy must be deeply rooted in everything related to the child's living space (family, kindergarten, school, extracurricular and educational institutions, social environment).

During the last decades, in Ukraine has been done a lot of the work to make childhood problems a state problem. Both at the legislative level (constitution, laws, resolutions of the Verkhovna Rada) and the executive (creation of the Ministry of Youth and Sports, the introduction of the post of Commissioner for the Rights of the Child of Ukraine). The state tries to create everything necessary to provide the younger generation with proper conditions for development.

Among the positive steps taken by the state are a number of important decisions to increase maternal care at birth, approval of a number of state programs on maternity and childhood care. In particular, the example of the Ministry of Health of Ukraine implemented a program for granting a child-friendly hospital status to those institutions that provide a high level of quality of medical services. It could be an exemplary example for pedagogical institutions. Why not give such a status to the best schools $-\mathrm{a}$ "pupils friendly school?!" It is noteworthy that the state has experience in creating family-type homes where both their own and foster children can be brought up in the family circle. At the same time, it should be remembered that there is a statewide network of orphanages and boarding schools for orphaned children that don't have sufficient government funding.

\footnotetext{
11 Эриксон Э. Г. Детство и общество. 2-е изд., перераб. и доп. СПб. : Ленато : Фонд Университет. кн., 1996. 592 с.
} 
It is obvious that the measures taken by the state to improve the demographic situation in Ukraine have yielded results. The number of newborns has increased significantly. But there was another problem - the lack of preschools. Some of them were alienated, some were rebuilt or demolished and the rest were repurposed.

Every child should have a chance for both physical and spiritual development in modern world. It is necessary to change our attitude towards the child - a complete perception as a person who is sovereign and has dignity. In this regard, it is also necessary to change the model of education: from a typical reactive one - which is realized under the influence of a certain situation, usually as a reaction to a child's negative behavior, to a proactive model - when we anticipate the situation, prevent mistakes, teach the child, explain to him what to do.

It is extremely important for parents in this sense to be proactive in teaching children values. A stable value system is not only one of the important conditions for life success but also protection against many wrong actions and external negative influences.

Modern society like the previous ones wants children to grow up to be intelligent, kind and happy people, be independent, create strong families, become full members of society. There is a disturbing disproportion between what society seeks and what we see around us: more and more children suffer from emotional disorders, demonstrate maladaptation to social life, suffer from depression and various addictions in modern Ukrainian society (narcotics, toxicological alcohol, gambling, etc.), committing suicide. Teachers state with dismay that children sometimes don't understand simple texts and tasks. Difficulties with language overlap with thinking problems. It happens in an increasingly complex world that needs more and more knowledge and intelligence.

The Ukrainian media space is full of reports of acts of aggression, violence, vandalism committed by children and youth, characterized by cruelty, senselessness, and the reasons for which they are committed seem 
absurd. Why are more and more children having problems and causing problems? Perhaps babies born now are worse off than those born fifty years ago. Obviously not. Children are born the same, with the same needs, but grow up in a completely different world than their grandparents and even parents. They receive less and less of what they need for healthy development: time and parental affection, intellectual encouragement, familiarity with the true culture, positive behaviors, and every thing more harmful: loneliness, violence directed against them, examples of aggression, anti-heroes. Their needs are emotional, mental, moral, neglected, leading to complete demoralization.

Among the lately global problems have plagued mankind is the problem of environmental (natural) protection. It is not time to realize to everyone that the natural environment of a person is social, as well as the culture created by him. According to professor of Cornell University J. Garbarino: "Today's society is poisonous and culture is toxic". It is the most poisonous effect understandably on the smallest social matter children ${ }^{12}$.

The environment our children grow up is - the family, the immediate environment (neighborhood, preschools, school, extracurricular institutions), society and its culture. African proverb says: "To raise a child, you need the involvement of the whole village".

Undoubtedly, the family is the environment in which a person must gain experience of social interaction, absorb the basic values will be guided in life.

Earlier, a few decades ago, in Ukrainian society, all educational institutions complemented and supported one another for the common good of the child, although it was happening in a system overburdened with an ideological component. Today we can state that a child can't find proper support and protection in any of them.

\footnotetext{
12 Ястребицкая А. Западная Европа ХІ - XIII веков. Эпоха, быт, костюм. М. : Искусство. 1978. $169 \mathrm{c}$.
} 
The outside world and economic development are changing the psychology of parents who are increasingly concerned about survival. Work, stress, lack of proper living conditions, confusion, increasing divorce rate, unemployment lead to a lack of time and energy for parents to care for their children. As a result - emotional disorders and loneliness of children. The respect for each other disappears in family relationships, interpersonal ties are broken, there is a lack of conscious learning of values.

At the same time, it is due to lack of time, psychological ignorance, underestimation of threats from the modern culture, parents don't protect children from negative influences and allow them many bad habits and actions: excessive watching of television programs (often contraindicated for children), Internet.

Parents sometimes buy computer games for their children, which teach them to abuse and kill others; parents are easily discouraged by changes in children's behavior that may signal drug addiction; parents don't notice that young girls have money, expensive gifts, clothing that can be "sponsored". A large number of parents are convinced that it is their duty to make money for the better financial status of the family and that the upbringing of the child is the responsibility of the preschool or school.

Today, Ukraine is among the countries with the highest rates of HIV- positive children and orphans. At the same time, the orphanage may also be with living parents who either abandon their children themselves or are deprived of this right by the state.

Few people are talking today about the other side of orphanage either working or orphaned. Ukrainians began to travel extensively abroad, mostly to European countries in the early 1990-th. The main reasons were economic troubles and uncertainty about tomorrow. The long stay abroad led to their partial or complete assimilation with Western society. Many of them have already naturalized in these countries, some of them are planning to return home. The vast majority of them, leaving Ukraine, left 
their children with their close relatives. Due to the long absence (most parents come only on big holidays), these children have received almost no proper family upbringing: parental warmth, understanding, support, love. It is obvious that parents helped them financially, taught, dressed, but it cannot replace their parental affection. Most likely here we can talk about certain moral obligations of parents to children, among which may be an effort to buy from a child for depriving her of a full-fledged childhood.

The problem of homelessness is also worth mentioning. Previously, this phenomenon was solitary. The number of children leaving parental homes is steadily increasing. More than two hundred thousand homeless minors are deprived of care, love and basic conditions for development. Many of them join the ranks of juvenile offenders.

In order for the child to become the center of the educational and upbringing process, he needs to help in this. Only adults (parents, teachers, educators) can do it. There is an opinion that it is necessary to start education in the family. We agree with it, but only when it comes to expectant parents and mothers. After all, the child learns from the example of his own family about the basics of family education. Subsequently society must do everything possible to ensure that the process of preparation for family life is not interrupted (school, university). The problem of parental training, as in the times of A. Makarenko, V. Sukhomlinsky, hasn't disappeared. Moreover, it has been exacerbated by the increasing number of divorces, the deformation of family relationships and so on.

For their part, there are educators who believe that the school should teach children, not educate. At school, children are not taught social norms of behavior and their negative, sometimes even bullying, actions are ignored or hidden by many teachers. It not only destroys the authority of educators, but also causes this behavior to escalate. It is sometimes absurd when central television channels broadcast a story shot on a cellphone by students scoffing at a teacher. Otherwise, as editorial ignorance, it will not 
call such things, but the position of a teacher who by his behavior attests to utter helplessness is not acceptable, because in his example it undermines the authority of hundreds of thousands of educators.

A school that lacks clear rules of conduct, a school where adults don't fulfill their educational functions is an unattractive or even threatening place for children, which promotes neither learning nor healthy development. Without the authority of the teacher, the school becomes a territory of impunity for aggressive and vulgar children and it cannot provide protection for the weak and the abused. The true authority of a teacher comes not from condemnation, punishment, but from one's own attitude toward students, others, professional responsibilities, life. After all, children need moral authority.

The majority of Ukrainian society agrees that the Ukrainian school needs significant changes in order to serve children. Today, it does not teach to think, the art of understanding, to be an honest, compassionate person, that is because in life it is most necessary. The predominant form of knowledge acquisition remains as before the acquisition by memory of an increasing amount of material in which with few exceptions, important for the social coexistence of knowledge are lost. By overburdening children with the ever-increasing amount of information the school doesn't even give them what has been available for a long time - modern teaching and learning technologies.

Placed in the "procrustean bed" of the curriculum, the teacher has no time for students as individuals. Taking care of young people in the most favorable period of their life - childhood, the school is generally irrationally managing their potential and not adequately preparing them for future life challenges.

There is no need to blame only the teachers: the system of education and upbringing should be changed. It is necessary to start by changing the model of preparation of future teachers. Today's teachers, frustrated by the low social status in society, low salaries, organizational prescriptions are 
sometimes helpless in conflict situations that arise in school. The need to talk about a system of values that the school would like to impart to the younger generation, but which cannot be separated from the adult value system has long matured in society. In a school that respects moral values such as respect, responsibility, self-discipline, honesty, solidarity, wisdom - both the children and the teacher will feel in their place. They will have the motivation to perfect themselves and enjoy the job well done.

The closest environment in the children's environment also includes the neighborhood (street, district, peer group). For a large number of children, it is not only a circle of friends, acquaintances, but also an anonymous environment where they can get their first negative experience of vulgarity, violence, experimentation with smoking, alcohol and drugs and more.

The political and social and economic transformation took place in Ukraine in the late XX-th - early XIX-th century in addition to positive changes the proclamation of independence, democratization of social life, led to a number of socio-economic difficulties.

The times of social protection of Ukrainian citizens have ended with the advent of the free market and privatization. The largest enterprises and even entire sectors of the economy, gave not only jobs, but also pulled "social" (sanatoriums, kindergartens, summer camps for children, houses of culture, sports facilities etc.) were in private hands. Many people have been unable to adapt to such radical changes in their lives. Entire regions find themselves in a zone of unemployment, cultural degradation, apathy and demoralization. All this leads to depopulation not only in rural areas but also in once powerful industrial cities.

But changes in Ukraine are not only the result of socio-economic transformation. Ukraine opened up the outside world and itself for it with independence. By building a democratic society with its attributes freedom of speech, freedom of religion, respect for human rights. It has increasingly received those associated negative phenomena that go hand in 
hand. The state has gained wide access to modern information technologies and ways of their broadcasting. Contemporary media are fueled by sensations, reports of violence, murder, acts of terror. Free communicating has led to previously unprecedented vulgarity and viciousness in the television space. Positive cognitive and cultural programs were somewhere on the margins of the Ukrainian television broadcast. It creates "evil world syndrome" and impedes the development of children, creating fear, arousing the unhealthy through the screens of computers and computers, instincts, teaching violence ${ }^{13}$.

Mass culture generates patterns to lower standards and the quality of relationships between people. The promoted values are: appearance, power, prosperity, life purpose - uncontrolled consumer activity and entertainment.

Modern culture has a significant impact on the younger generation, ultimately teaches that it will lead to life-threatening consequences in the future, to the lack of respect for oneself and others, selfishness, heartlessness, violence, the absence of any moral norms.

Due to the dominance of the media and the lack of parental care, childhood is slowly losing its status as a particularly worrying and protective society. Children are attacked by pictures of the darker sides of adulthood, daily experiencing the manifestations of violence and evil. It is constantly pouring out of television screens, irretrievably losing the extremely important attributes of childhood - feelings of safety, carelessness, innocence.

They become adults in advance. It which doesn't mean mature at all, rather on the contrary. The absence of parents (or their part) in the life of the child puts them at greater risk of being used by other adults.

Culture is not just about media and entertainment.It's also a way of behaving on the bus, at school, in the shops, on the street and ultimately in the family. Parenting has always been a difficult task. When we become

\footnotetext{
13 Кись О. Материнство и детство в украинской традиции: деконструкция мифа. Социиальная история. Ежегодник 2003. М.: Российская политическая энциклопедия. 2003. С. 156-172.
} 
parents we have to realize that we will have to give up for the sake of a child. This is the maturity of a person when we see the meaning in it and do it without feeling of our own loss.

To prepare children well for life is to give them life force, vital immunity and vital competences. It can be achieved by taking care of the emotional needs of children. Meeting these needs will be for them the best vaccination against external adverse effects.

Therefore the most urgent problems of childhood in Ukraine include the lack of a single long-term program that outlines concrete measures. It should be taken to ensure that a child in the country has legal, social, psychological and pedagogical, economic, medical, cyber-digital protection. All agencies must be involved in the adoption of this program, since children are as much members of society as adults. They are the same service consumers, customers, passengers, viewers.

The greatest responsibility for the implementation of the childcentered approach in education and training lies with the specialists teachers, tutors, psychologists, social educators. Therefore special attention should be paid to the content of teacher education, which in fact has not changed for a long time.

We can take for example the psychological pedagogical unit which includes disciplines in pedagogy, psychology, methodology. Teachers and psychologists are trained not only by traditional (mostly state) universities but pedagogical universities in Ukraine.

All of the above gives reason to determine that the state should unify approaches to the training of pedagogical specialists, no matter where it is carried out. The content of psychological and pedagogical disciplines in addition must meet the modern needs of society in the specialists who can successfully fulfill his (society) requests for the final product.

Only a democratic state, civil and legal society can ensure the stable social development of its citizens and the upbringing of the younger generation in the spirit of true humanism. As society and peoples in 
different parts of the world have defined the basic form of their life or coexistence with other peoples, the state must assume the responsibility and responsibility for the safety and proper living conditions of its citizens, especially the younger generation - its physical, moral development, quality education and the best education which inherently involves childcentered pedagogy which should become not pedagogy for the child but pedagogy of the child.

\section{CONCLUSIONS}

The positive consequences of the implementation of child-centered ideas in the practice of modern school activities are substantiated. It consists in the research nature of the learning process, and hence the formation of cognitive interests of students; enriching, expanding and supplementing the primary competencies of students; aspirations of increase of own educational potential; creating conditions for students' creative activity.

The relevance of the ideas of child-centrism in the upbringing, determination of the chil's living space and substantiation of his rights are determined. Today, more than ever, the problem of the care and upbringing of all children, including those who have become street children for various reasons, becomes important.

The modern world is also changing the legal status of the child: recognizing the rights in conjunction with a number of duties is an important task of the present. It is analyzed the implementation of childcentric ideas in the national educational space. Positive steps of the state towards creating a child-centered living space of the individual (legislative initiatives, social programs, etc.) have been identified.

\section{SUMMARY}

The article deals with the importance of axiological formation of the younger generation. It was noted that parents should play a leading role in 
this process. There are however problems in family education related to parental over-employment or absence.

It has been determined that the phenomenon of employment has left a large number of children with orphans, who having good financial support are deprived of their main - emotional connection with their parents and their support. The school is also partly eliminated from fulfilling its educational responsibilities. Older models often remain to relevant education, depriving pupils of the possibility to feel the subjects of selfcreation and self-education.

Attention is paid to the modern training of pedagogical staff in pedagogical and classical universities, points out both the shortcomings of the training of prospective teachers and possible ways of their solution, in particular the unification of approaches to the training of pedagogical specialists regardless of where it is carried out. The article emphasizes on the necessity that the state should take on the responsibility and responsibility for the safety and proper living conditions of citizens, especially the young generation - its physical, moral development, qualitatively new education and the best education, provides pedagogy of child-centrism.

\section{REFERENCES}

1. Illich I. Społeczeństwo bez szkoły. Warszawa : PIN, 1976. S. 219.

2. Schoenebeck H. Thema Schule. Was Eltern und Lehrer schon tun kőnnen-20 Vorschlage, Freudschaft mit Kindern. Münster, 1981. Р. 8-11.

3. Права дитини: від витоків до сьогодення: зб. текстів, метод. та інформ. матеріалів. Авт.-упоряд. Г. М. Лактіонова. К. : Либідь. 2002. $277 \mathrm{c}$.

4. Права дитини: європейський досвід. упоряд. Н. М. Костяк. Львів: ПАІС. 2007. 113 с.

5. Лутай В. Філософія сучасної освіти. К. : Центр «Магістр - S» Творчої спілки вчителів України, 1996. 360 с. 
6. Дитинство в Україні: права, гарантії, захист. голов. ред. В. І. Довженко. К.: АТ Вид-во “Столиця”, 1998. 290 с.

7. Гонтаровська Н. Б. Освітнє середовище як фактор розвитку особистості дитини. Д. : Дніпро. 2010.622 с.

8. Кремень В.Г. Філософія освіти XXI століття. Педагогіка $i$ психологія: Вісник АПН України. 2003. № 1. С. 6-16.

9. Щеглова С. Н. Как изучать детство? Социологические методы исследования современных детей и современного детства. М.: ТО ЮНПРЕСС, 2000. $72 \mathrm{c}$.

10. Эриксон Э. Г. Детство и общество. 2-е изд., перераб. и доп. СПб. : Ленато : Фонд «Университет. кн.», 1996. 592 с.

11. Ястребицкая А. Западная Европа XI - XIII веков. Эпоха, быт, костюм. М. : Искусство. 1978. 169 с.

12. Кись О. Материнство и детство в украинской традиции: деконструкция мифа. Социальная история. Ежегодник 2003. М.: «Российская политическая энциклопедия». 2003. С. 156-172.

\section{Information about the author:} Kvas O. V.

Doctor of Pedagogical Sciences, Professor, Head of the Department of General Pedagogy and Pedagogy of Higher School, Ivan Franko National University of Lviv 7, Tuhan Baranoskiy str., Lviv, 79000, Ukraine 